\title{
Hydrogen Generation by Means of Hydrolysis Using Activated Al-In-Bi-Sn Composites for Electrochemical Energy Applications
}

\author{
S.P. du Preez and D.G. Bessarabov ${ }^{*}$ \\ HySA Centre of Competence, North-West University (NWU), Potchefstroom Campus, Private Bag \\ X6001, Potchefstroom, 2520, South Africa \\ *E-mail: dmitri.Bessarabov@ nwu.ac.za
}

doi: $10.20964 / 2017.09 .22$

Received: 12 April 2017 / Accepted: 30 June 2017 / Published: 13 August 2017

\begin{abstract}
Effective activation compounds are developed to produce hydrogen via hydrolysis of ball-milled AlIn-Bi-Sn composites in tap water at room temperature. Al-In-Bi-Sn composites are successfully activated by $3 \mathrm{~h}$ of milling. These composites exhibit hydrogen yields $>85 \%$ between 2.5 min (fastest reaction time) and $14 \mathrm{~min}$ (slowest reaction time). The intermetallic phases responsible for $\mathrm{Al}$ activation, $\mathrm{InSn}_{4}, \mathrm{InBi}$ and $\mathrm{In}_{3} \mathrm{Sn}$, are selectively synthesized, identified and characterized. The reaction kinetics of each intermetallic phase are determined after ternary composite preparation, i.e., milling $\mathrm{Al}$ with In and $\mathrm{Bi}$ or $\mathrm{Sn}$. Quaternary composites are also prepared to determine the formation kinetics of the intermetallic phases. These quaternary composites have high hydrogen yields (> 90\%) and the reactions are complete within $170 \mathrm{~s}$. The formation of intermetallic phases is responsible for the structural failure of $\mathrm{Al}$, resulting in the size reduction of $\mathrm{Al}$ particles. The following are also investigated and quantified: the effects of water volume and reaction temperature on hydrolysis kinetics, and the activation energies of ternary $\mathrm{Al}$ composites.
\end{abstract}

Keywords: Activated aluminum; Hydrogen generation; Mechanochemical activation

\section{$\underline{\text { FULL TEXT }}$}

(C) 2017 The Authors. Published by ESG (www.electrochemsci.org). This article is an open access article distributed under the terms and conditions of the Creative Commons Attribution license (http://creativecommons.org/licenses/by/4.0/). 